\title{
Analisis Pengembangan Usaha Pemanfaatan Limbah Bonggol Jagung Menjadi Produk Kerajinan Multiguna
}

\author{
Mahardhika \\ Departemen Manajemen, Fakultas Ekonomi dan Manajemen \\ Institut Pertanian Bogor \\ Kampus Baranangsiang Bogor 16144 \\ Farida Ratna Dewi \\ Departemen Manajemen, Fakultas Ekonomi dan Manajemen \\ Institut Pertanian Bogor \\ Kampus Darmaga Bogor 16680 \\ e-mail: reidadewi@gmail.com
}

\begin{abstract}
The rest of the agricultural industry on corn will produce waste in the form of corncobs whose number will continue to rise in line with increased production. Increased agricultural production, in this case the corn, must be accompanied by further efforts in the form of management, and preservation, so that waste materials (corn stalks) that have been manufactured not reduce the aesthetic environment or do not cause environmental pollution. One of the creative ideas to reduce the volume of waste corncobs and increase its added value is to convert these wastes to be multipurpose craft products. UKM Bonggol Jagung Craft is an UKM that produces multipurpose craft through the utilization of waste corncobs. The advantages of such products are located on the aesthetic value and uniqueness that can be displayed by the nature and structure of the raw material waste corncobs. The purpose of this research is 1) to analyze the feasibility of the development of the tuber Corn Craft market in terms of aspects, technical aspects, management aspects, social aspects of economic and environmental aspects; 2) analyze the feasibility of the development of the tuber Corn Craft in terms of the criteria analysis Net Present Value (NPV), Internal Rate of Return (IRR), Net Benefit/Cost (Net B/C), Payback Period (PP), R/C Ratio, Return On Investment (ROI), and Break Event Point (BEP); 3) To analyze the level of sensitivity (sensitivity) for utilization of waste corncobs into multipurpose craft products on Bonggol Jagung Craft event of an increase in the total cost (total cost), the decline in sales, as well as the combination of an increase in the total cost (total cost) with a decline in sales. The Result of this research about the market aspects, technical aspects, management aspects, social aspects of economic and environmental aspects, and financial aspects are feasibel.
\end{abstract}

Keywords: corncobs, multipurpose craft, UKM, criteria analysis, sensitivity, feasibility

\section{ABSTRAK}

Sisa pengolahan industri pertanian pada jagung akan menghasilkan limbah berupa bonggol jagung yang jumlahnya akan terus bertambah seiring dengan peningkatan kapasitas produksi. Peningkatan produksi pertanian jagung dalam hal ini harus disertai dengan upaya lebih lanjut dalam bentuk manajemen, pelestarian, dan penggunaan limbah bahan bonggol jagung yang telah diproduksi tidak mengurangi estetika lingkungan atau tidak menyebabkan pencemaran lingkungan. Oleh karena itu, salah satu ide kreatif dalam mengurangi volume limbah bonggol jagung dan meningkatkan nilai tambahnya adalah dengan memanfaatkan limbah bonggol jagung untuk diubah menjadi produk kerajinan yang multiguna. UKM Kerajinan Bonggol Jagung adalah sebuah UKM yang menghasilkan kerajinan multiguna melalui pemanfaatan limbah bonggol jagung. Keuntungan yang ada di produk ini terletak pada nilai estetika dan keunikan tersendiri yang dapat ditampilkan oleh sifat dan struktur dari bahan baku bonggol jagung. Tujuan dalam penelitian ini adalah 1) Menganalisis kelayakan 
pengembangan usaha pada UKM Bonggol Jagung Craft ditinjau dari aspek pasar, aspek teknis, aspek manajemen, aspek sosial ekonomi, dan aspek lingkungan; 2) Menganalisis kelayakan pengembangan usaha pada UKM Bonggol Jagung Craft dilihat dari sisi kriteria analisis NPV, IRR, Net B/C, PBP, R/C Ratio, ROI, dan BEP; 3) Menganalisis tingkat kepekaan (sensitivitas) usaha pemanfaatan limbah bonggol jagung menjadi produk kerajinan multiguna pada Bonggol Jagung Craft apabila terjadi peningkatan total biaya, penurunan penjualan, serta kombinasi antara peningkatan total biaya dengan penurunan penjualan. Hasil penelitian ini menunjukkan bahwa aspek pasar, aspek teknis, aspek manajemen, aspek sosial ekonomi dan aspek lingkungan, serta aspek keuangan adalah layak.

Kata kunci: bonggol jagung, kerajinan multiguna, UKM, analisis kriteria, sensitivitas, kelayakan

\section{Pendahuluan}

Indonesia merupakan salah satu negara agraris (agriculture country) yang mempunyai berbagai ragam hasil pertanian mulai dari padi, ubi kayu, jagung dan sejumlah hasil pertanian lainnya yang sangat penting dalam perindustrian nasional. Di sisi lain, produk hasil pertanian dikenal tidak tahan lama dan mudah rusak yang disebabkan karena rendahnya kualitas penanganan pasca panen, kandungan air yang relatif tinggi, serta faktor-faktor lain yang lekat dengan karakteristik biologis dan fisiologis produk agronomi itu sendiri. Kegiatan pascapanen dan pengolahan hasil pertanian termasuk pemanfaatan produk sampingan dan sisa pengolahan yang masih kurang menyebabkan jumlah limbah pertanian terus menerus meningkat.

Berdasarkan data Status Lingkungan Hidup Indonesia (SLHI) tahun 2011, limbah organik mencapai angka $70 \%$, sedangkan limbah non organik mencapai angka $30 \%$. Salah satu limbah organik yang ada di Indonesia adalah limbah bonggol jagung. Limbah bonggol jagung secara produktivitas per hektar menduduki tempat terendah dibandingkan limbah pertanian lainnya. Tetapi karena areal tanaman jagung yang cukup luas dan umur tanamannya relatif pendek (75-120 hari setelah masa tanam) sehingga panen bisa diperoleh beberapa kali dalam setahun akibatnya hasil produksi dan total limbahnya cukup berimbang dengan limbah pertanian lainnya kecuali padi. Jagung memiliki nilai ekonomis yang cukup tinggi selain dapat dinikmati hanya dengan direbus namun dapat juga diolah menjadi makanan kering (digoreng atau dioven) yang akan memperlama umur ekonomis hasil olahan jagung tersebut.

Sisa pengolahan industri pertanian pada jagung akan menghasilkan limbah berupa bonggol jagung yang jumlahnya akan terus bertambah seiring dengan peningkatan kapasitas produksi. Oleh karena itu, salah satu ide kreatif dalam mengurangi volume limbah bonggol jagung dan meningkatkan nilai tambahnya adalah dengan memanfaatkan limbah bonggol jagung untuk diubah menjadi produk kerajinan yang multiguna seperti yang dilakukan oleh UKM Bonggol Jagung Craft. Proses ini membutuhkan biaya dan waktu yang tidak sedikit serta membutuhkan tingkat kreativitas yang sangat tinggi karena merupakan industri kreatif sehingga diperlukan uji kelayakan untuk pengembangan usaha tersebut. Perumusan masalah dalam penelitian ini antara lain :

1. Bagaimanakah kelayakan pengembangan usaha pada UKM Bonggol Jagung Craft ditinjau dari aspek pasar, aspek teknis, aspek manajemen, aspek sosial ekonomi, dan aspek lingkungan?

2. Bagaimanakah kelayakan pengembangan usaha pada UKM Bonggol Jagung Craft dilihat dari sisi kriteria analisis Net Present Value (NPV), Internal Rate of Return 
(IRR), Net Benefit/Cost (Net B/C), Payback Period (PP), R/C Ratio, Return On Investment (ROI), dan Break Event Point (BEP) ?

3. Bagaimana tingkat kepekaan (sensitivitas) usaha pemanfaatan limbah bonggol jagung menjadi produk kerajinan multiguna pada UKM Bonggol Jagung Craft apabila terjadi peningkatan total biaya, penurunan penjualan, serta kombinasi antara peningkatan total biaya dengan penurunan penjualan ?

Tujuan dalam penelitian ini adalah 1) Menganalisis kelayakan pengembangan usaha pada UKM Bonggol Jagung Craft ditinjau dari aspek pasar, aspek teknis, aspek manajemen, aspek sosial ekonomi, dan aspek lingkungan; 2) Menganalisis kelayakan pengembangan usaha pada UKM Bonggol Jagung Craft dilihat dari sisi kriteria analisis NPV, IRR, Net B/C, PBP, R/C Ratio, ROI, dan BEP; 3) Menganalisis tingkat kepekaan (sensitivitas) usaha pemanfaatan limbah bonggol jagung menjadi produk kerajinan multiguna pada Bonggol Jagung Craft apabila terjadi peningkatan total biaya, penurunan penjualan, serta kombinasi antara peningkatan total biaya dengan penurunan penjualan.

\section{Metode Penelitian}

Layaknya sebuah usaha sebelum didirikan harus melalui proses uji kelayakan terlebih dahulu agar pemilik dapat mengetahui prospek dan risiko dari usaha yang akan dijalankan. Sehingga perlu dikaji kelayakan dari aspek finansial dan nonfinansial. Aspek finansial meliputi NPV, Net B/C, IRR, dan PP, sedangkan aspek nonfinansial meliputi aspek pasar, teknis, manajemen, sosial, dan lingkungan. Setelah diketahui dari kedua aspek dinilai apakah layak atau tidak maka kemudian ditentukan keputusannya.

Penelitian ini dilakukan di UKM Bonggol Jagung Craft, Jl. Pembangunan 2 No. 42, Kedung Halang Bogor. Penelitian dilakukan selama tiga bulan yang dimulai dari bulan Maret 2012 sampai Mei 2012. Jenis data yang digunakan dalam penelitian ini adalah data primer dan data sekunder. Data primer diperoleh dengan melakukan pengamatan langsung di lapangan dan wawancara kepada pemilik usaha Bonggol Jagung Craft. Data sekunder ini diperoleh dari pengkajian terhadap data literatur yang mendukung topik penelitian ini seperti data Badan Pusat Statistika, data Dinas Perindustrian dan Perdagangan, buku-buku yang memuat teori-teori, jurnal, skripsi, maupun penelusuran melalui internet.

Pengumpulan data dilakukan dengan dua cara, yaitu sebagai berikut:

1. Riset Kepustakaan (library research).

Riset kepustakaan mengarah pada pengumpulan data yang dilakukan dengan mempelajari literatur, dokumen usaha, dan mengutip pendapat dari berbagai sumber buku yang bersifat ilmiah, yang berkaitan dengan objek penelitian, serta penelusuran internet.

2. Riset Lapangan (field research).

a. Wawancara (interview)

Wawancara dilakukan secara terstruktur menggunakan daftar pertanyaan yang telah dipersiapkan untuk mengetahui informasi terkini tentang usaha Bonggol Jagung Craft dari mulai mempertanyakan profil usaha, kelengkapan dokumen penelitian, dan informasi seputar usaha yang dijalankan. Wawancara dilakukan 
dengan pemilik usaha Bonggol Jagung Craft maupun pihak-pihak yang terkait dalam aktivitas usaha Bonggol Jagung Craft.

b. Pengamatan (observation)

Pengamatan dilakukan langsung ke usaha dan lokasi kegiatan guna memperoleh data keterangan yang diperlukan seperti proses produksi, fasilitas produksi, tenaga kerja, manajemen usaha, pencatatan keuangan, dan lain-lain.

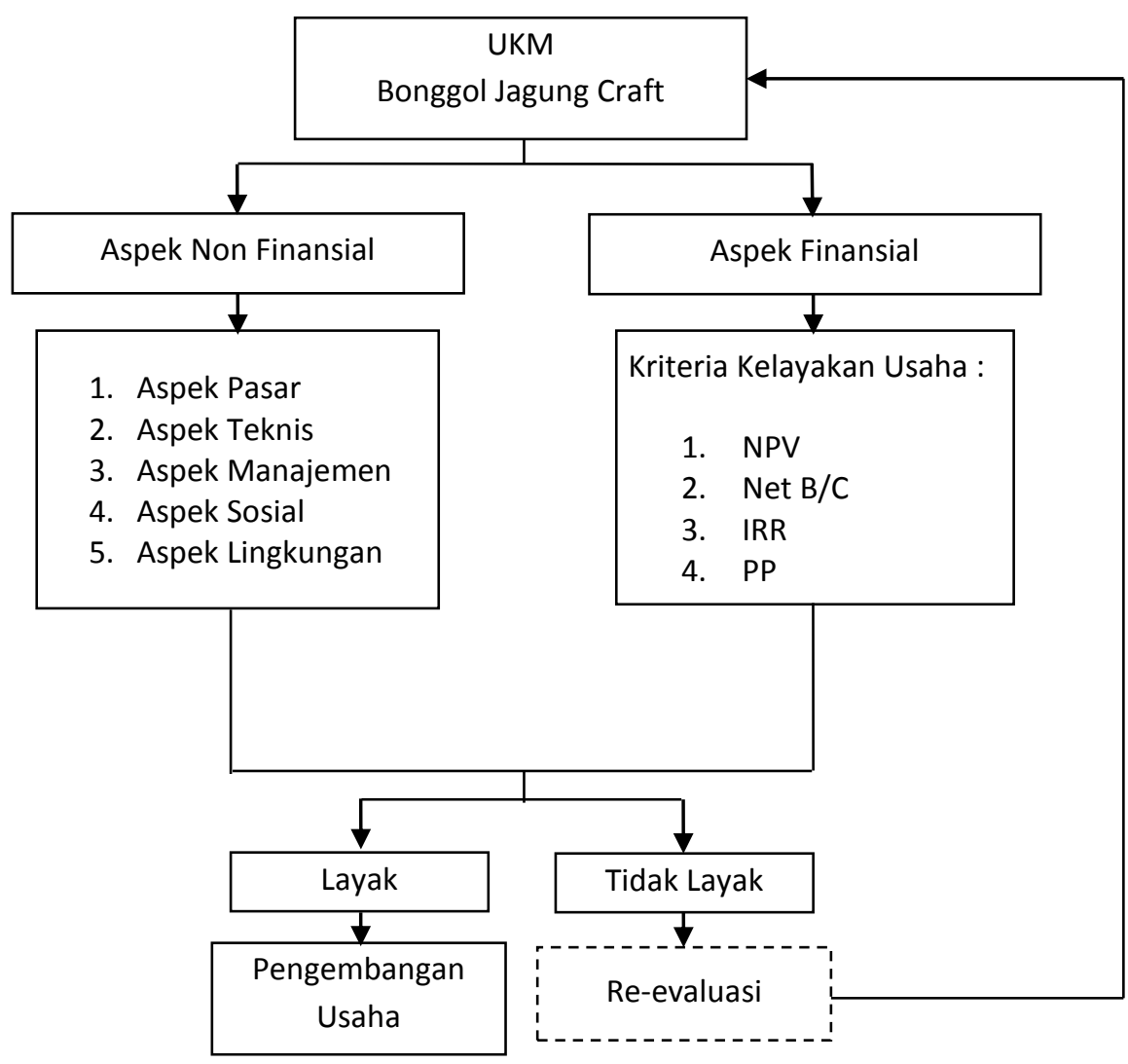

Gambar 1. Kerangka pemikiran operasional lain:

Metode pengolahan dan analisis data yang digunakan dalam penelitian ini antara

1. Analisis Kelayakan Finansial

a. Return On Investment (ROI)

Return On Investment adalah kemampuan suatu usaha untuk menghasilkan keuntungan (Rangkuti 2001). Rumus yang digunakan adalah:

$$
\mathrm{ROI}=\frac{\text { Keuntungan }}{\text { Investasi }} \times 100 \% \ldots \text {. (1) }
$$

b. Payback Period (PBP)

Masa Pengembalian Investasi (MPI) atau payback period adalah suatu indikator yang dinyatakan dengan ukuran waktu untuk menentukan berapa tahun yang diperlukan oleh proyek untuk mampu mengembalikan biaya investasi yang dikeluarkan perhitungan MPI adalah sebagai berikut: 


$$
\mathrm{P}=\frac{\mathrm{V}}{\mathrm{I}}
$$

Dimana:

$\mathrm{P}=$ Waktu yang diperlukan untuk mengembalikan modal investasi

$\mathrm{V}=$ Jumlah modal investasi

$\mathrm{I}=$ Manfaat bersih rata-rata per periode

c. Net Present Value (NPV)

Net Present Value (NPV) merupakan nilai sekarang dari selisih benefit (keuntungan atau manfaat) dengan cost (biaya) pada tingkat suku bunga tertentu yang ditimbulkan oleh investasi (Husnan dan Suwarsono 1999). Perhitungan NPV adalah sebagai berikut:

$$
\mathrm{NPV}={ }_{t=1}^{n} \frac{B_{t}-C_{t}}{(1+i)^{t}} \ldots \ldots
$$

Dimana:

$\mathrm{Bt}=$ Manfaat yang diterima

$\mathrm{Ct}=$ Biaya (cost) pada tahun ke-t

$\mathrm{i}=$ Tingkat discount rate $(\%)$

$\mathrm{n}=$ Umur proyek (tahun)

$\mathrm{t}=1,2,3, \ldots$.

Dalam metode NPV terdapat tiga kriteria kelayakan investasi yaitu:

1. NPV $>0$; maka proyek menguntungkan dan dapat dilaksanakan

2. NPV $=0$; maka proyek tidak untung tetapi juga tidak rugi, jadi tergantung pada penilaian subjektif pengambil keputusan

3. NPV < 0 ; maka proyek ini merugikan karena keuntungan lebih kecil daripada biaya, sehingga lebih baik proyek ini tidak dilaksanakan

d. Internal Rate of Return (IRR)

Internal Rate of Return (IRR) merupakan tingkat discount rate yang membuat NPV dari suatu proyek sama dengan nol (Gittinger 1986). Suatu usaha atau kegiatan investasi dinyatakan layak apabila IRR lebih besar dari tingkat discount rate yang ditentukan. Sebaliknya jika nilai IRR lebih kecil dari tingkat discount rate, maka usaha atau kegiatan investasi tidak layak untuk dijalankan. Menurut Kadarsan (1995) rumus perhitungan IRR adalah sebagai berikut:

Dimana:

$$
\begin{aligned}
& \text { IRR }={ }_{t=1}^{n} \frac{B_{t}-C_{t}}{(1+I R R)^{t}}=0 \ldots \ldots \text { (4) } \\
& \text { IRR }=I^{\prime}+\frac{N P V^{\prime}}{N P V^{\prime}-N P V^{\prime \prime}} \times\left(\mathrm{i}^{\prime \prime}-\mathrm{i}^{\prime}\right) \ldots(5)
\end{aligned}
$$

$\mathrm{i}^{\prime} \quad=\quad$ Tingkat discount rate yang menghasilkan NPV positif

$\mathrm{i}^{\prime \prime} \quad=$ Tingkat discount rate yang menghasilkan NPV negatif

$\mathrm{NPV}^{\prime}=$ Nilai bersih sekarang yang bernilai positif

NPV" = Nilai bersih sekarang yang bernilai negatif

$\mathrm{t}=1,2,3, \ldots, \mathrm{n}$ 
e. Titik Impas (Break Even Point)

Titik impas (Break Even Point) adalah suatu keadaan dimana total penghasilan yang didapatkan sama dengan total biaya yang dikeluarkan. Rumus yang digunakan dalam menghitung BEP adalah sebagai berikut:

$$
\begin{aligned}
& \text { BEP produksi }=\frac{\text { Biaya Tetap }}{\text { Harga per unit }- \text { Biaya variabel per unit }} \ldots \text { (6) } \\
& \text { BEP nilai }=\frac{\text { Biaya Tetap }}{1-(\text { Biaya var } / \text { total penerimaan 1tahun })} \ldots \ldots \text { (7) }
\end{aligned}
$$

\section{f. Net Benefit Cost ratio (Net B/C)}

Net Benefit Cost Ratio atau Net B/C Ratio merupakan angka perbandingan antara jumlah present value yang bernilai positif dengan jumlah present value yang bernilai negatif atau dalam arti lain merupakan angka perbandingan antara nilai kini arus manfaat dibagi dengan nilai sekarang arus biaya. Kriteria yang digunakan untuk pemilihan ukuran $\mathrm{B} / \mathrm{C}$ ratio adalah memilih semua proyek yang dinilai B/C ratio sebesar satu atau lebih jika arus biaya dan manfaat dapat didiskontokan pada tingkat biaya oportunitas capital (Gittinger 1986). Rumus yang digunakan dalam perhitungan $\mathrm{B} / \mathrm{C}$ ratio adalah sebagai berikut:

$$
\text { Net } \mathrm{B} / \mathrm{C}=\frac{\prod_{t=1}^{n} \frac{B_{t}-C_{t}}{(1+i)^{t}}\left(\text { untuk } B_{t}-C_{t}>0\right)}{n_{t=1}^{n} \frac{B_{t}-C_{t}}{(1+i)^{t}}\left(\text { untuk } B_{t}-C_{t}<0\right)}
$$

Dimana:

$\mathrm{Bt}=$ Penerimaan pada tahun ke- $\mathrm{t}$

$\mathrm{Ct}=$ Biaya pada tahun ke- $\mathrm{t}$

$\mathrm{i}=$ Tingkat Discount rate $(\%)$

$\mathrm{n}=$ Umur proyek (tahun)

Dengan kriteria:

a. Net $\mathrm{B} / \mathrm{C} \geq 1$, maka proyek layak dan menguntungkan

b. Net $\mathrm{B} / \mathrm{C}<1$, maka proyek tidak layak dan tidak menguntungkan

\section{g. Analisis Sensitivitas}

Analisis ini dipergunakan untuk melihat dampak perubahan keadaan yang memungkinkan terjadi terhadap suatu hasil analisis. Analisis ini menggunakan asumsi jika ada perubahan seperti kenaikan total biaya, penurunan penjualan atau dapat terjadi secara bersamaan dimana total biaya naik namun penjualan menurun.

2. Analisis Kelayakan Non Finansial

Analisis non finansial yang meliputi aspek pasar, teknis, manajemen, sosial ekonomi, dan lingkungan dengan menggunakan analisis deskriptif.

\section{Hasil dan Pembahasan}




\section{III.1. Aspek Non Finansial}

\section{Aspek Pasar}

a. Produk

Produk yang dihasilkan ada dua jenis produk multiguna yaitu produk lampu kartu nama, dan produk lampu hias. Produk lampu kartu nama dirancang sebagai tempat kartu nama dan ballpoint yang dikombinasi dengan cahaya lampu yang bisa diatur hidup atau mati, diletakkan untuk memperindah ruangan yang lebih resmi seperti ruang kerja, ruang pertemuan, dan ruang tamu. Produk lampu hias dirancang sebagai hiasan ruangan yang lebih santai maupun formal, baik itu meja kerja, kamar tidur, disudut ruangan maupun ditempel pada dinding.

b. Harga

UKM Bonggol Jagung Craft menjual produknya dengan harga Rp 300 000/unit pada dua jenis produknya. Harga yang ditetapkan juga sudah menutupi biaya yang dikeluarkan dan memberikan keuntungan untuk UKM Bonggol Jagung Craft.

c. Distribusi

Pola distribusi dilakukan dengan menggunakan saluran langsung (sederhana), di mana pembeli dapat langsung melakukan pemesanan kepada UKM Bonggol Jagung Craft. Perusahaan tidak memiliki agen, karena dirasa jika menggunakan pihak kedua harga produk akan lebih mahal sampai ke tangan konsumen akhir.

d. Promosi

Strategi promosi yang dilakukan UKM Bonggol Jagung Craft dalam memasarkan produknya adalah:

1) Direct Selling Product

Direct selling yang dilakukan dengan menjual produk pada event-event tertentu seperti bazar, ekspo, pameran, pasar rakyat, dan lain-lain.

2) Internet

UKM Bonggol Jagung Craft memiliki web blog, youtube, dan facebook. Adapun webblognya yaitu: ilovebonggoljagung.blogspot.com, dan akun facebooknya yaitu ediebonggoljagung.craft. Stasiun tv lokal maupun swasta juga sering meliput: Trans TV, berita Liputan 6 SCTV, Liputan MNCTV, dan lainlain. Juga melalui media cetak online seperti Kompas.com, www.radarbogor.co.id, dan lain-lain.

3) Pelatihan ke instansi pemerintah daerah

Pelatihan yang ditawarkan berupa pelatihan proses pembuatan bonggol jagung dari mulai proses pembersihan hingga proses perakitan dan finishing.

4) Membuat kartu nama dan ex-banner

Kartu nama dibuat sebagai sarana promosi kepada relasi bisnis atau konsumen secara luas. Ex-banner dibuat sebagai sarana promosi ditempat umum dengan harapan dapat menjadi daya tarik konsumen.

\section{Aspek Teknis}

a. Lokasi Usaha

Usaha Bonggol Jagung Craft sendiri terletak di Jl. Pembangunan 2 No.42 Kedung Halang Bogor. Akses transportasi berupa jalan raya dan kendaraan umum juga sangat memadai sehingga tidak terlalu menjadi masalah dalam hal penyediaan bahan baku dan proses distribusinya. 
b. Proses Produksi

Produk yang dihasilkan dari pemanfaatan limbah bonggol jagung oleh Bonggol Jagung Craft ini berupa produk kerajinan bonggol jagung. Proses produksi dimulai dari pembersihan bahan baku (bonggol jagung), kemudian dilakukan perendaman dan dilanjutkan dengan proses pengeringan (dijemur). Proses selanjutnya adalah perataan dan pemotongan dilanjutkan dengan penempelan dan perakitan disesuaikan dengan bentuk produknya. Langkah selanjutnya adalah penghalusan dan sanding dan terakhir adalah packing.

c. Peralatan dan Perlengkapan Produksi

Peralatan dan perlengkapan dibagi berdasarkan alur proses produksi terdiri dari pisau, keranjang plastik, karung, terpal, mesin penghalus modif, alat gergaji otomatis, kardus, mesin gergaji siku, meja produksi, cetakan pola, solder, palu, tang, gunting, kursi, penggaris besi, penggaris siku, jangka, cutter, isi cutter, mesin amplas otomatis, alat bor vertikal, dan kuas.

3. Aspek Manajemen dan Hukum

a. Perizinan dan Legalitas Badan Hukum Usaha

Dalam hal perizinan, UKM Bonggol Jagung Craft sudah memiliki izin usaha yang dikeluarkan oleh Badan Perizinan Terpadu Pemerintah Kabupaten Bogor berupa Surat Izin Usaha Perdagangan (SIUP) untuk usaha skala kecil dengan nomor 00390/03-20/PK/PO/III/2007.

b. Struktur Organisasi

Struktur organisasi UKM Bonggol Jagung Craft sendiri masih sangat sederhana. Hampir semua fungsi manajerial dipegang sendiri oleh pimpinan usaha sekaligus pemiliknya. Pemilik usaha langsung membawahi 4 orang karyawan. Pembagian tugas secara spesifik dilakukan pada proses produksinya di mana terdapat empat kegiatan utama dalam proses produksi, yaitu pembersihan, pemotongan, perakitan, dan finishing. Dengan struktur organisasi seperti ini, pengambilan keputusan dalam segala hal menjadi wewenang dari pemilik usaha.

4. Aspek Sosial Ekonomi

Dalam aspek sosial ekonomi akan dilihat seberapa besar kontribusi dari usaha yang ada terhadap kehidupan sosial dan ekonomi dari lingkungan sekitar tempat usaha didirikan. Dilihat dari aspek sosial, dengan adanya Bonggol Jagung Craft di Kedung Halang Bogor akan membuka peluang kesempatan kerja dan dapat menyerap tenaga kerja dari masyarakat sekitar. Secara tidak langsung keberadaan usaha ini dapat membantu pemerintah daerah Kabupaten Bogor dalam upaya mengurangi angka pengangguran walaupun dalam jumlah kecil. Sehingga secara sosial, usaha ini dapat diterima dengan baik oleh masyarakat sekitar selain dapat menyerap tenaga kerja lokal juga karena limbah dari sisa-sisa bahan merupakan limbah organik bahkan dapat menjadi bahan campuran pembuatan pupuk organik. Dari segi ekonomi, keberadaan Bonggol Jagung Craft dapat meningkatkan jumlah pendapatan baik pemilik usaha maupun masyarakat sekitar serta pemerintah daerah.

5. Aspek Lingkungan 
Pengembangan usaha Bonggol Jagung Craft dapat dikatakan tidak menghasilkan sisa atau limbah yang dapat mengganggu lingkungan sekitar. Sisa atau limbah produksi pada umumnya berupa sisa sesetan dan debu bonggol jagung. Sisa sesetan saat pembersihan jagung biasanya digunakan sebagai campuran kompos yang digunakan untuk memupuk tanaman dirumahnya. Sedangkan debu bonggol jagung saat proses pemotongan dimanfaatkan sebagai bahan perekat komplemen lem epotec saat menempel dan merakit kepingan maupun batangan bonggol jagung.

\section{III.2. Aspek Finansial}

\section{Asumsi Finansial}

Dalam pengembangan usaha bonggol jagung ini ditetapkan beberapa asumsi dasar yang digunakan sebagai indikator dalam perhitungan. Asumsi dasar yang digunakandapat dilihat pada Tabel 1.

Tabel 1. Asumsi finansial

\begin{tabular}{|c|c|c|c|}
\hline No & Asumsi & Satuan & Nilai / Jumlah \\
\hline 1 & Periode proyek & tahun & 10 \\
\hline 2 & Hari kerja per bulan & hari & 26 \\
\hline 3 & Bulan kerja per tahun & bulan & 12 \\
\hline \multirow[t]{4}{*}{4} & Output, Produksi dan Harga: & & \\
\hline & a. Produksi kerajinan (awal) dalam bulan & unit & 30 \\
\hline & b. Produksi kerajinan (awal) dalam tahun & unit & 360 \\
\hline & c. Harga penjualan kerajinan & Rp/unit & 300000 \\
\hline \multirow[t]{2}{*}{5} & Kerusakan : & & \\
\hline & a. Produksi & $\%$ & 0 \\
\hline \multirow[t]{5}{*}{6} & Penggunaan input utama dan harga: & & \\
\hline & a. Bonggol jagung 1 bulan & karung & 3 \\
\hline & Harga Bonggol jagung & Rp/karung & 20000 \\
\hline & b. Lem Epotec 1 bulan & dus & 5 \\
\hline & Harga Lem Epotec & $\mathrm{Rp} / \mathrm{dus}$ & 250000 \\
\hline 7 & Suku Bunga Deposito per Tahun & $\%$ & 7.14 \\
\hline \multirow[t]{3}{*}{8} & Proporsi Modal : & & \\
\hline & a. Kredit & $\%$ & 0 \\
\hline & b. Modal Sendiri & $\%$ & 100 \\
\hline 9 & Peningkatan produksi tiap tahun & $\%$ & 10 \\
\hline
\end{tabular}

\section{Rencana Kebutuhan Fisik}

Rencana kebutuhan fisik pada usaha bonggol jagung merupakan suatu perencanaan mengenai kebutuhan fisik yang diperlukan oleh usaha mulai dari awal hingga periode usaha akan berakhir. Kebutuhan fisik ini terdiri dari bangunan dan lahan untuk tempat usaha, peralatan dan perlengkapan produksi, bahan baku produksi, energi, dan tenaga kerja. Kebutuhan bangunan berupa sebuah rumah yang mempunyai lahan berukuran $150 \mathrm{~m}^{2}$ yang digunakan untuk mendukung seluruh aktifitas usaha, mulai dari produksi, administrasi, dan penjualan. Peralatan dan perlengkapan produksi yang dibutuhkan relatif banyak dan terdiri dari berbagai jenis, sesuai tahap produksi yang dilakukan, mulai dari tahap pembersihan, pemotongan, perakitan, dan finishing.

3. Rencana Anggaran Biaya 
Rencana anggaran biaya merupakan rekapitulasi dari seluruh biaya yang dibutuhkan dalam pengembangan usaha Bonggol Jagung Craft. Biaya-biaya yang termasuk dalam rencana anggaran biaya terdiri dari berbagai macam diantaranya biaya perizinan, bangunan, lahan, biaya peralatan dan perlengkapan investasi produksi, biaya bahan baku produksi, biaya tenaga kerja tetap, biaya peralatan dan perlengkapan tetap, biaya energi (listrik dan air), biaya telepon, dan biaya transportasi. Ringkasan rencana anggaran biaya dapat dilihat pada Tabel 2.

Tabel2. Ringkasan rencana anggaran biaya

\begin{tabular}{lc}
\hline \multicolumn{1}{c}{ Komponen Biaya } & Anggaran Biaya (Rp) \\
\hline Perizinan & 500000 \\
Bangunan & 55000000 \\
Lahan & 22500000 \\
Peralatan \& Perlengkapan & 7163750 \\
Investasi & 37170000 \\
Bahan Baku Produksi & 36000000 \\
Tenaga Kerja & 3036000 \\
Peralatan dan Perlengkapan & 4800000 \\
Tetap & 1800000 \\
Energi ( Listrik \& Air ) & 3000000 \\
Telepon & $\mathbf{1 7 0 9 6 9 7 5 0}$ \\
Transportasi & Total
\end{tabular}

\section{Biaya Operasional}

Biaya operasional merupakan biaya yang dibutuhkan usaha untuk menjalankan roda perusahaan dan aktifitas operasionalnya. Pada pengembangan usaha bonggol jagung, biaya operasional pada tahun pertama yang dibutuhkan sebesar Rp 85806 000. Biaya operasional terdiri dari biaya variabel (variabel costs) dan biaya tetap (fixed costs). Biaya variabel adalah biaya yang besar kecilnya selaras dengan perkembangan produksi atau penjualan setiap satu satuan waktu. Besarnya biaya variabel pada pengembangan usaha ini adalah Rp 37170 000. Biaya variabel ini terdiri dari biaya untuk bahan baku utama produksi dan bahan baku pembantu produksi. Biaya tetap merupakan biaya yang jumlahnya tidak terpengaruh oleh perkembangan jumlah produksi atau penjualan dalam satu satuan waktu. Besarnya biaya tetap pada pengembangan usaha ini sebesar Rp 48636000 . Biaya tetap pada pengembangan Bonggol Jagung Craft terdiri dari gaji tenaga kerja tetap, peralatan dan perlengkapan tetap, listrik, air, telepon, dan transportasi. Ringkasan biaya operasional dapat dilihat pada Tabel 3.

Tabel 3. Ringkasan biaya operasional

\begin{tabular}{cc}
\hline \multicolumn{1}{c}{ Biaya Operasional } & Jumlah Biaya (Rp) \\
\hline Biaya Variabel (variabel costs) & 37170000 \\
Biaya Tetap (fixed costs) & 48636000 \\
\hline \multicolumn{1}{c}{ Total } & $\mathbf{8 5 8 0 6 0 0 0}$ \\
\hline
\end{tabular}

\section{Modal dan Penerimaan}


Modal merupakan keseluruhan biaya yang diperlukan untuk membangun dan menjalankan usaha. Untuk melakukan pengembangan usaha bonggol jagung ini, pemilik tidak melakukan peminjaman modal kepada pihak kreditur, karena pemilik telah menyediakan persiapan modal dalam melakukan suatu pengembangan usaha. Komponen modal sendiri terdiri dari biaya investasi yang dilakukan pada tahun ke 0 dan dana modal kerja selama satu bulan pada saat memulai kegiatan usaha pada tahun ke 1. Dana yang dialokasikan untuk investasi pada usaha Bonggol Jagung Craft digunakan untuk memenuhi kebutuhan perizinan, bangunan, lahan, dan peralatan serta perlengkapan investasi produksi.Keseluruhan biaya investasi berjumlah Rp 85163 750. Sedangkan dana modal kerja terdiri dari biaya produksi, gaji tenaga kerja, biaya peralatan dan perlengkapan, kebutuhan listrik dan air, dan alokasi biaya lain seperti telepon dan transportasi. Jumlah biaya yang dibutuhkan untuk dana modal kerja sebesar Rp 7150 500. Jadi total rencana kebutuhan modal pada periode awal pengembangan usaha Rp 92314 250, yang terdiri dari kebutuhan investasi tahun ke nol Rp 85163 750, dan modal kerja selama 4 minggu (1 bulan) Rp 7150500.

Arus penerimaan memuat semua komponen yang merupakan pemasukan dalam bisnis, pada saat permulaan atau selama bisnis berjalan. Komponen yang terdapat dalam arus penerimaan pada pengembangan usaha Bonggol Jagung Craft terdiri dari penjualan hasil produksi dan nilai sisa. Penjualan hasil produksi merupakan total penerimaan dari penjualan kerajinan bonggol jagung yang diproduksi dengan nilai total sebesar Rp 108000 000. Pada pengembangan usaha bonggol jagung ini diasumsikan peningkatan produksi sebesar $10 \%$ tiap tahunnya sehingga adanya peningkatan produksi menyebabkan sisi penerimaan juga ikut meningkat.

\section{III.3. Analisis Kriteria Investasi}

Analisis kriteria investasi yang digunakan pada pengembangan usaha Bonggol Jagung Craft terdiri dari Net Present Value (NPV), Internal Rate Return (IRR), Net Benefit Cost Ratio (Net B/C), Payback Period (PP), dan Return On Investment (ROI). Kelayakan pengembangan usaha dilakukan dengan melihat pendapatan bersih usaha pembuatan kerajinan bonggol jagung tersebut pada tingkat suku bunga $7.14 \%$ yang merupakan rata-rata suku bunga deposito bank (Bank Persero, Bank Pemerintah Daerah, Bank Swasta Nasional, Bank Asing \& Campuran, Bank Umum) pada bulan Januari tahun 2011 hingga bulan Maret 2012. Hasil perhitungan dari analisis kriteria investasi dapat dilihat pada Tabel 4 di bawah ini.

\begin{tabular}{clcc}
\multicolumn{4}{c}{ Tabel } \\
\hline No & \multicolumn{1}{c}{ Nilai kriteria investasi pengembangan usaha Bonggol Jagung Craft } \\
\hline 1 & Net Present Value (NPV) & Satuan & Nilai \\
2 & Internal Rate of Return (IRR) & $\mathrm{Rp}$ & 327167596 \\
3 & Net Benefit Cost Ratio (Net B/C) & $\%$ & 44.67 \\
4 & Payback Period (PP) & - & 4.84 \\
5 & Return On Investment (ROI) & tahun & 2.07 \\
\hline
\end{tabular}

Nilai NPV pada pengembangan usaha Bonggol Jagung Craft ini adalah Rp 327167 596. Hal ini menunjukkan bahwa pengembangan usaha layak dijalankan karena NPV yang dihasilkan lebih besar dari nol (NPV >0) dan bernilai positif. Sedangkan Nilai IRR pada pengembangan usaha Bonggol Jagung Craft adalah 44.67\%. 
Hal ini berarti bahwa keuntungan internal atau benefit internal yang diperoleh usaha ini dari investasi yang ditanamkan selama umur proyek adalah sebesar $44.67 \%$ per tahun. Angka ini lebih besar dari tingkat suku bunga deposito yang ditetapkan sebesar 7.14\% yang berarti modal yang ditanamkan dalam usaha Bonggol Jagung Craft akan mempunyai tingkat pengembalian yang lebih menguntungkan dibandingkan melakukan investasi dalam bentuk deposito di bank sehingga usaha pengembangan ini layak dilaksanakan.

Berdasarkan nilai Net $B / C$ pada pengembangan usaha Bonggol Jagung Craft ini adalah 4.84. Karena nilai Net $B / C$ ini lebih besar dari satu maka usaha layak untuk dijalankan. Hasil perhitungan didapatkan nilai Payback Perioddari pengembangan usaha Bonggol Jagung Craft yaitu selama 2.07 tahun (2 tahun 21 hari ). Nilai ini lebih kecil dari umur maksimum proyek yaitu 10 tahun sehingga layak untuk dijalankan. Nilai $R O I$ pengembangan usaha Bonggol Jagung Craft adalah 26\%. Nilai ini menunjukkan bahwa setiap rupiah yang ditanamkan sebagai modal investasi UKM Bonggol Jagung Craft dapat memberikan keuntungan sebesar Rp 0.26. Berdasarkan kriteria ROI, hal ini dapat dikatakan bahwa usaha Bonggol Jagung Craft ini menguntungkan. UKM Bonggol Jagung Craft akan mencapai titik impas jika penjualan adalah sebesar Rp 89764498 dan berproduksi pada kapasitas 299 unit. Artinya, pengembangan usaha Bonggol Jagung Craft harus berproduksi sejumlah minimal nilai tersebut dalam setiap tahun agar dapat menutupi biaya produksinya.

III.4. Analisis Sensitivitas

1. Kenaikan Total Biaya (Total Cost) $44.7 \%$

Tabel 5. Perbandingan nilai kriteria investasi akibat kenaikan total cost sebesar $44.7 \%$ pada UKM Bonggol Jagung Craft

\begin{tabular}{clccc}
\hline \multirow{2}{*}{ No } & \multicolumn{1}{c}{$\begin{array}{c}\text { Kriteria } \\
\text { Investasi }\end{array}$} & $\begin{array}{c}\text { Sebelum Kenaikan Total } \\
\text { Cost }\end{array}$ & $\begin{array}{c}\text { Setelah Kenaikan Total } \\
\text { Cost }\end{array}$ & Perubahan \\
\hline 1 & NPV (Rp) & 327167596 & -425818.76 & 327593414.76 \\
2 & IRR (\%) & 44.67 & 7.09 & 37.58 \\
3 & Net B/C & 4.84 & 0.99 & 3.85 \\
4 & PBP (tahun) & 2.07 & 10 & 7.93 \\
5 & R/C Ratio & 1.26 & 0.87 & 0.39 \\
6 & ROI (\%) & 0.26 & -0.19 & 0.45 \\
\hline
\end{tabular}

2. Penurunan Penjualan $28,7 \%$

Tabel 6. Perbandingan nilai kriteria investasi akibat penurunan penjualan sebesar $28.7 \%$ pada UKM Bonggol Jagung Craft

\begin{tabular}{clccc}
\hline No & \multicolumn{1}{c}{$\begin{array}{c}\text { Kriteria } \\
\text { Investasi }\end{array}$} & $\begin{array}{c}\text { Sebelum Penurunan } \\
\text { Penjualan }\end{array}$ & $\begin{array}{c}\text { Setelah Penurunan } \\
\text { Penjualan }\end{array}$ & Perubahan \\
\hline 1 & NPV (Rp) & 327167596 & $-425818,75$ & 327593414.75 \\
2 & IRR (\%) & 44.67 & 7.08 & 37.59 \\
3 & Net B/C & 4.84 & 0.99 & 3.85 \\
4 & PBP (tahun) & 2.07 & 10 & 7.93 \\
5 & R/C Ratio & 1.26 & 0.90 & 0.36 \\
6 & ROI (\%) & 0.26 & -0.10 & 0.36 \\
\hline
\end{tabular}

3. Kenaikan Total Biaya (Total Cost) $24.5 \%$ dengan Penurunan Penjualan $13.1 \%$ 
226|Mahardika, Dewi - Analisis Pengembangan Usaha Pemanfaatan Limbah Bonggol Jagung

Tabel 7. Perbandingan nilai kriteria investasi sebelum dan sesudah kenaikan total biaya (total cost) $24.5 \%$ dan penurunan penjualan $13.1 \%$ pada UKM Bonggol Jagung Craft

\begin{tabular}{clccc}
\hline No & $\begin{array}{c}\text { Kriteria } \\
\text { Investasi }\end{array}$ & $\begin{array}{c}\text { Sebelum Kenaikan Total } \\
\text { Cost dan Penurunan } \\
\text { Penjualan }\end{array}$ & $\begin{array}{c}\text { Setelah Kenaikan Total Cost } \\
\text { dan Penurunan Penjualan }\end{array}$ & Perubahan \\
\hline 1 & NPV (Rp) & 327167596 & -425851 & 327593447 \\
2 & IRR (\%) & 44.67 & 7.09 & 37.58 \\
3 & Net B/C & 4.84 & 0.99 & 3.85 \\
4 & PBP (tahun) & 2.07 & 10 & 7.93 \\
5 & R/C Ratio & 1.26 & 0.88 & 0.38 \\
6 & ROI (\%) & 0.26 & -0.15 & 0.41 \\
\hline
\end{tabular}

\section{Kesimpulan}

Kelayakan pengembangan usaha pada UKM Bonggol Jagung Craft dilihat dari aspek non finansial menunjukkan bahwa usaha pemanfaatan limbah bonggol jagung menjadi produk kerajinan multiguna ini layak untuk dijalankan. Kelayakan pengembangan usaha pada UKM Bonggol Jagung Craft dilihat dari sisi kriteria analisis layak dilakukan, dimana NPV yang dihasilkan pada tingkat suku bungadeposito $7.14 \%$ adalah Rp 327167 596, IRR menghasilkan nilai 44.67\%, NetB/C 4.84. Payback Period diperoleh nilai 2.07 tahun, $\mathrm{R} / \mathrm{C}$ ratio sebesar 1.26, dan $\mathrm{ROI}$ diperoleh sebesar $26 \%$. Nilai BEP yang diperoleh sebesar Rp 89764498 dan BEP produksinya sebanyak 299 unit. Berdasarkan hasil analisis tingkat kepekaan (sensitivitas), pengembangan usaha kerajinan Bonggol Jagung Craft mengalami kondisi tidak layak apabila terjadi peningkatan total biaya (total cost) sebesar $44.7 \%$, penurunan penjualan sebesar $28.7 \%$, serta kombinasi peningkatan total biaya (total cost) sebesar $24.5 \%$ dengan penurunan penjualan sebesar $13.1 \%$

\section{Daftar Pustaka}

Gittinger JP. 1986. Analisis Ekonomi Proyek-Proyek Pertanian. Edisi Kedua. Jakarta (ID): UI Press.

Husnan S, Suwarsono. 1999. Studi Kelayakan Proyek. Edisi Revisi. Unit Penerbit dan Percetakan AMP. Yogyakarta (ID): YKPN.

Kadarsan HW. 1995. Keuangan Pertanian dan Pembiayaan Perusahaan Agribisnis. Jakarta (ID): Gramedia Pustaka Utama.

Rangkuti F. 2001. Business Plan Teknik Membuat Perencanaan Bisnis dan Analisis Kasus. Jakarta (ID) : PT Gramedia Pustaka Utama. 